\title{
Postwar Korean Cinema
}

\author{
By Toh, Hai Leong \\ Fall 1996 Issue of KINEMA \\ POSTWAR KOREAN CINEMA: FRACTURED MEMORIES AND IDENTITY
}

IT IS generally agreed by South Korean film scholars that the Golden Flowering of Korean cinema took place in the turbulent 1950s after the end of the 1950-53 Korean War, amidst the rapid industrialisation and modernisation of a predominantly agrarian society based on a highly stratified class system. Like its highly reactive Hongkong counterpart, South Korean cinema acts as a sensitive reflection of the constant changes and upheavals -- both socio-economic and political. These include the liberation in 1945 from Japan, the Korean War, the 1970s economic miracle and the current traumatic transformations that are shaping this troubled peninsula.

This year, the astute Asian programmer of the 20th Hongkong International Film Festival, Ms Wong Ain-ling introduced a total of 12 "Rediscovered Korean Classics," with 6 of them set in the 1950s and 60s, emphasising the important role of Korean women during these periods. Opening the retrospective were three major films with strong female leads, namely The Free Woman (Han Hyong-mo, 1956), Housemaid (Kim Ki-yong, 1960) and The Guest and My Mother (Sin Sang-ok, 1961). In the last of the three films, the young and beautiful repressed widow, played brilliantly by Korean cinema's screen legend Choe Un-hui, is beyond a shadow of a doubt the epitome of the self-sacrificing woman who lives solely for the memories of her late husband and for her sweet and good-natured but naive daughter. However she is not without conflict and is highly troubled by the passion the artist-tenant feels for her. He communicates his feelings through her daughter whom he takes as a friend and confidante.

The college professor's wife in The Free Woman is initially a traditional Korean housewife -- the image of her married life is seemingly one of marital harmony. Unlike the good widow in The Guest and My Mother, she is drawn to things Western -- pop music, record player, nightclubs and modern fashion. Yet like Un-hui, she cannot totally repudiate her servile, traditional and affirming womanhood. She finally comes to her senses when she receives a slap from her lover's wife and realises she must return to where she belongs.

Housemaid, however, is a total departure from the conventional filmic depiction of Korean women bound by Confucian subservience and docility. Instead, the film introduces a manipulative, menacing woman who is determined to wreak havoc on the binding ties of the Korean family and by extension, the nation. Inspired by a real-life incident, it is a hotly controversial tale of a maid who seduces the master of the household and precipitates the demise of the family and the highly stratified Korean society. In the film, music teacher Mr. Kim is no more the supreme patriarch, because he is earning less money than his spouse, who is obsessed with acquiring better housing and material goods. Feeling emasculated and overwhelmed by his undissipated libido the husband starts a torrid affair with the maid. Gradually, the maid begins to manipulate him and threatens to expose their liaison and even suggests they commit double-suicide.

The portrayal of the "aberrant woman" goes through a drastic change: from the 1956 The Free Woman who realises her folly and repents, to the monstrous character in the 1960 Housemaid, who destroys the traditional middle-class family adhering to Confucian practices and principles.

At about this time, Yu Hyun-mok's expressionistic masterpiece shot in monochrome, Aimless Bullet (1960), was made. This was followed a year later by Kang Tae-jin's The Coachman inspired by DeSica and Sin Sang-oks masterwork The Guest and My Mother.

Both Aimless Bullet and The Coachman are supreme realist films, showing the influence of Italian Neorealism, particularly that of Roberto Rossellini and Vittorio DeSica. The former is shot in highly-stylised monochrome, with dark shadows suggesting the evil social forces of the modernising Korean society obsessed with money-making. The latter is a melodrama about coachman Ha, a widower who takes pride in his honesty and integrity and whose son passes the state law only after the fourth try.

In Aimless Bullet, the major characters are disillusioned war veterans from a Northern family who had abandoned their home after the August 1945 liberation. Poorly paid public accountant Song Chol-ho, with 
a severe case of toothache, has a mother driven mad by the war and a pregnant wife who dies in her labour. His handsome brother robs a bank to acquire quick money to impress his beautiful actress-fiancee and to give his ill-fortuned family something to live for. Rejected by a war-scarred soldier, his sister turns to prostitution, servicing the American GI's.

In Yu's bleak universe, hope is almost non-existent. The metaphor of the severe toothache which almost costs the despondent hero his life etches itself deeply into our smug and complacent existence. From the cosy darkness and safety of the cinema seat, we start to feel guilty even for the minor character of the film, a pessimistic poet who kills his girlfriend who has a one-night stand with Song's good-looking brother. Like the aimless bullet of the film's title, the characters are trapped hopelessly in their vicious circle of poverty as darker days loom over the horizon. If there is any sense of affirmation, it is perhaps to be discerned in Song's naive daughter who is oblivious to her father's poverty and suffering and who instead dreams of a pair of new shoes.

The family of coachman Ha, a widower with three adult children, is in a state of flux and crisis. His eldest son has failed his law exam three times, his younger son is mixed up with hoodlums and his mute daughter is brutalised by an insensitive husband who keeps a mistress. Has only comfort is a gentle widow who cares for him and keeps his house; he is also proud of his horse which is loyal and works for him without complaint. In bringing up the relationship between $\mathrm{Ha}$ and his callous employer, the film highlights the gulf that exists within the class system -- that of the haves and the have-nots, the rich oppressors and the oppressed working class.

Almost parallelling the coachman's plight is the 1963 film Daughters of Pharmacist Kim by Yu Hyun-mok. Kim's mother had committed suicide eighteen years ago after a disastrous love affair; she had not been able to endure her husband's jealous rage. Now, years later, he takes his four daughters to return to live in their ancestral home with his wife. The four young women vary in temperament and personality. The eldest is cold and distant, the second is a nerd, the third is a tomboy obsessed with sex and the youngest is a patient and obedient Protestant. The tragedy that once struck Kim's family with the death of his mother begins once again to manifest itself. Although the film Daughters is sometimes almost surreal in the presentation of the female characters, it is nevertheless a brilliant critique of Korean morality and the social intercourse between sexes in the patriarchal society at a time when the country was opening up to the world.

The rapidly modernising South Korea in the 1970s is represented by a quixotic road-movie Road to Sampo (1975) by the late director Yi Manhui. Alternatively titled Way to Sampo, unfinished and open-ended, the film depicts the winter journey of two men and a woman travelling through a country in swift transition. The affable lead, Chong, while making his way to his native village Sampo, weaves magical tales about it as they trek through the thick snow and forbidding cold. But the Sampo of Chong's memories exists no more; it has been transformed beyond recognition.

Korean cinema of the 1970s was in a state of decline after nearly two decades of flowering. In 1973, the Motion Picture Promotion Corporation was formed to save the near bankrupt industry from sinking further. The only significant films to come out of it were Road to Sampo and Lee Jung-sob (directed by Kwang Chong-hwan, (1975). Thus it is understandable that one major representative film has been selected for the HKIFF.

Fortunately, the 1980s saw a great change -- a change for the better. This was initially started by feature films inspired by documentary and short film production, leading to the emergence of fresh talents like Park Kwang-su, Chang Sun-woo, Lee Chang-ho, Bae Chang-ho, Park Jong-won and rejuvenated veteran talents like Im Kwon-taek. Three of Im's masterpieces from the 1980s have been unearthed for the film festival: Tchakko (1980), The Misty Village (1982) and Ticket (1986).

The subject of low-life which hovers and survives in the fringes of society is well portrayed in Lee Chang-ho's cynical Declaration of Fools and Im's Ticket based on a true story of a Korean eastern seaport town where waitresses' "tickets" (disguised prostitution) are being sold in a tea shop.

If Forrest Gump could name a predecessor, it might well be Lee's protagonist Tongchol in Declaration of Fools. A cripple, thief, pickpocket, beggar and later a pimp, Tongchol discovers that the pretty "girl-student" whom he has kidnapped is in fact a prostitute. Accompanied by his equally moronic, naive fat slob of a 


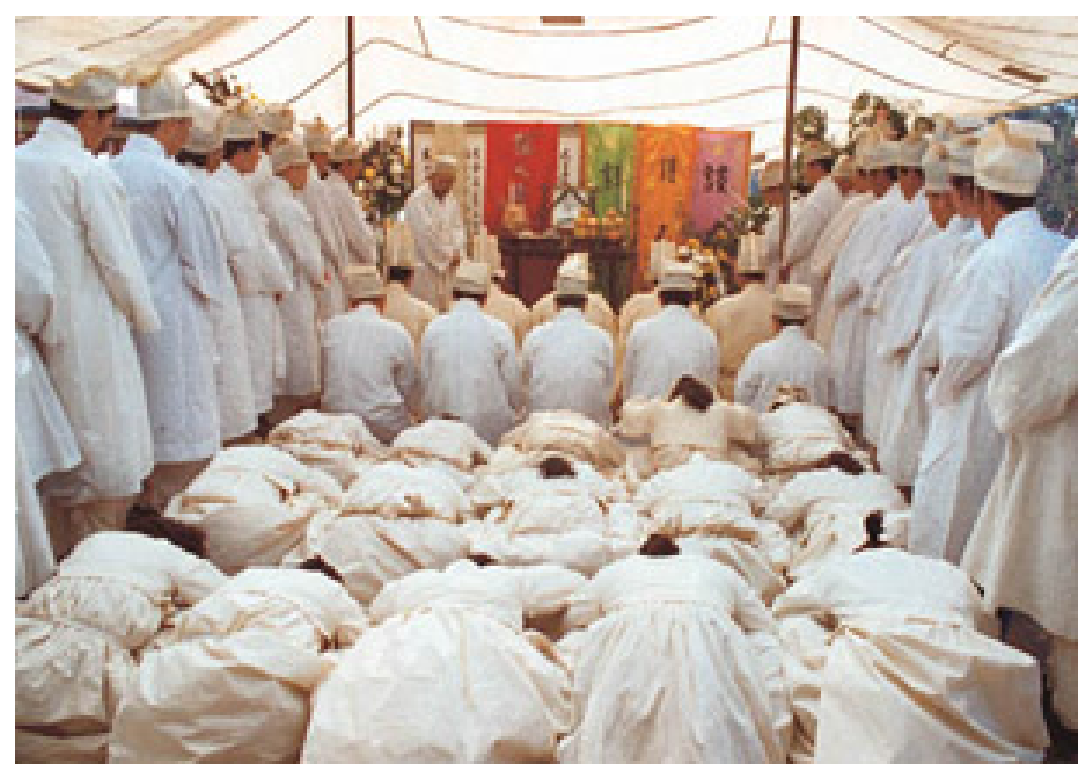

Figure 1: Festival (dir. Im Kwon-taek, 1996)

taxi-driver friend, together they bump from one place to another aimlessly with the prostitute in tow. The film is almost like a silent movie, with hardly thirty lines of dialogue; it feels like an avant-garde experiment.

In Ticket, Im Kwon-taek casts a compassionate tale of the saddened lives of Chisuk, a woman café-cumbrothel owner and of her "waitresses" in a port town. Chisuk herself falls for a jailed poet who later marries into a rich bourgeois family. An indictment of the corrupt ways of capitalism through monetary transactions for young girls flesh, Ticket is strangely sympathetic to the fate of the exploited women. We pity the school-girl-turned-whore who supports her boyfriend's studies and subsidies her brother's marriage. We also emphasize with Chisuk whose love for the poet ends in betrayal. In this film Im's technique of intercutting the sad lives of the girls in a collage-like style produces extremely powerful results.

Im's 1980 film Tchakko takes the theme of conflicting ideologies to new heights. A tale of a leftist partisan (communist) and a rightist soldier who are at each others' throats during and after the Korean War, the filmmaker breaks new artistic grounds. Im lets the two antagonists fight out their deadly struggle to its logical conclusion. He questions the rightness of ideologies as upheld by the two warring parties asking: "What does it matter really if in the end death is the master of all ideologies?"

Im's The Misty Village (1982) is set in an insular picturesque village in the Tanyang-Palkyong region. It is a morality study of human sexuality, repression and taboo seen through the eyes of Han Suok, the new teacher posted there. In this closely-knit community whose members are somehow related one to another, she discovers that Kae-chol, the village idiot, is somehow linked to the community's closely-guarded secret. The secret comes to light when she seeks shelter from a freak storm in the mill and encounters Kae-chol and is raped by him. In her view she experienced the first "orgasmic affair." She realises that Kae-chol fulfills the sexual needs of the unloved and abandoned village women. She also starts to comprehend the menfolks' silent acceptance of the situation, their closed-door compromises and their need to save face for themselves and their clan.

The last Korean classic to close the retrospective was the well-chosen Bae Chang-ho's Deep Blue Night (1984). Before Peter Weir's Green Card (1990), there was Bae's Deep Blue Night, a film about a handsome but brutal Korean man who marries a rich divorcee to get his green card in the land of freedom, opportunity, and money. Leaving South Korea for America, Gregory Beck [sic!] (played by the excellent Ahn Sung-ki) leaves behind a pregnant fiancee and immediately seduces a rich married woman whom he beats up and leaves for dead in Death Valley. Using the money he has cheated out of her, he marries a rich divorcee in Los Angeles to get his green card. He gets his lawful residency, his wife falls slowly for his charms but his Korean fiancee 
can no longer wait for him. The betrayed woman he had abused returns to seek compensation, his fake wife refuses to divorce him and the Law finally closes in on him.

Due to highly stylised visuals and good acting of the two leads -- Ahn Sung-ki as the brutal male and the cold beauty Chang Mee-hee as the divorcee, Deep Blue Night makes for compulsive viewing as a critique of the vain quest of contemporary Koreans for the good life in strange lands. The film opens with an image of the arid and empty Death Valley and ends with the same image -- but in the end it is the vast nothingness that reigns. Deep Blue Night signalled the arrival of the slick Hollywood melodrama in South Korean cinema and was one of the most successful box office hits of 1984 .

It is impossible to do justice to the entire range of post-war Korean cinema in this article. It is with renewed hope and enthusiasm that the now 60-year old internationally renowned master. Im Kwon-taek and his younger colleagues will continue to produce quality films in the years to come. The Rediscovered Korean Classics' retrospective was an eye-opener in showing the complexity of South Korean cinema and its ability to address pertinent issues which confront Korean society.

Finally, one observation has to be made with regard to the Korean retrospective: This is that Hongkong viewers regard eroticism as the main criterion for seeing a Korean film. As such, films like Housemaid, The Misty Village and Ticket attracted large crowds whereas masterful works like Aimless Bullet, Coachman, Road to Sampo, Daughters of Pharmacist Kim, Declaration of Fools and Deep Blue Night drew only thin audiences.

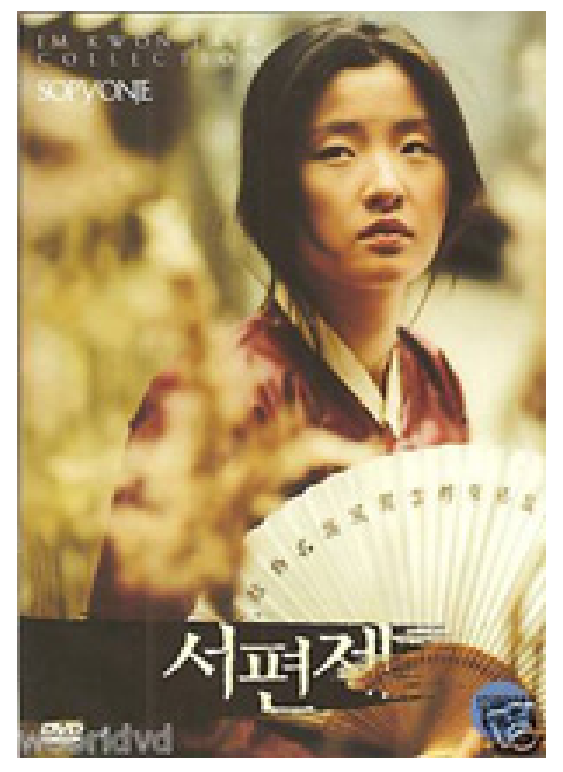

Figure 2: Sopyonje (dir. Im Kwon Taek, 1993)

\section{Author Information}

TOH Hai Leong is a Singapore-based freelance film critic and filmmaker (Zombie Dogs, 2005) who writes for independent film publications such as Screen International and World Paper. He has covered the Hong Kong International Film Festival since 1985 and specializes in the cinemas of Hong Kong, Taiwan, China, Korea and Japan. 